\title{
SAARC Countries and ENT Conferences
}

\section{R Guragain}

Editor-in chief

The South Asian Association for Regional Cooperation (SAARC) is an organization of South Asian nations, founded in December 1985 and dedicated to economic, technological, social and cultural development emphasizing collective self-reliance. Its seven founding members are Bangladesh, Bhutan, India, Maldives, Nepal, Pakistan, and Sri Lanka. Afghanistan joined the organization in 2007. Meetings of heads of state are usually scheduled annually; meetings of foreign secretaries, twice annually. The headquarter is in Kathmandu, Nepal.

Many organizations/associations after the name of SAARC were formed later. Medical speciality is no exception. There are many SAARC associations in medical fields according to the speciality. However, in ENT it took many years to form a SAARC ENT Association. It was possible in 1998 in Dhaka, Bangladesh for finally form an SAARC ENT Association with the following aims:

to promote closer ties and friendship amongst the national societies of Otolaryngologists of SAARC countries in particular.

- to organise meetings (Congress, seminar etc)so that otolaryngologists of SAARC can exchange views, information, experiences etc.

- to help elevate the standard of training and practice in otolaryngology and Head Neck Surgery in SAARC countries.

- to encourage exchange of expertise

- to help in exchange of technical know-how and get the industries to exhibit their products in the neighbouring countries.

to make a directory of experts in different fields over a period of time.

The SAARC ENT Conference is usually held every two years in the capital cities of the member countries. So far Bangladesh has organised it twice - 1 st in 1998 and 6th in 2008. Nepal hosted the conference in 2000 and now in 2011, Pakistan in 2002, Srilanka in 2004 and India in 2006. Bhutan, Maldives and Afghanistan have yet to open their account in organizing the conference.

Nepal hosted as mentioned previously the 2 nd conference and going to host the forthcoming 7th conference in May. We wish the conference a grand success.
CURRENT MEMBERS OF SAARC (ALPHABETICALLY)

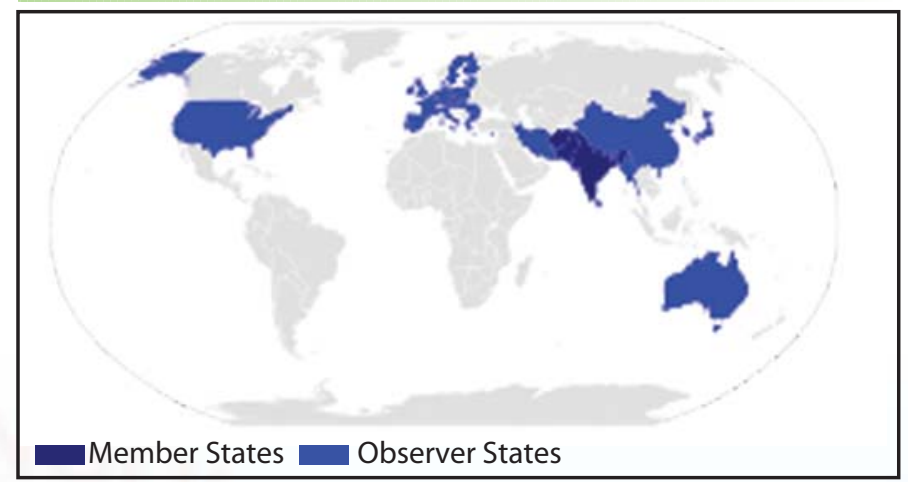

Member States

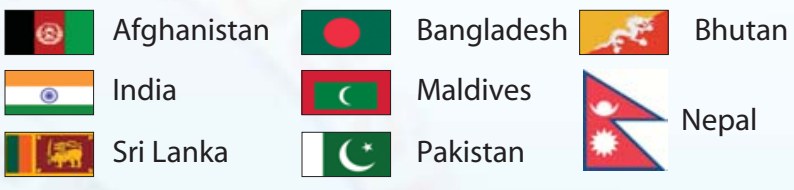

Observer States

\begin{tabular}{|c|c|c|c|}
\hline $\begin{array}{l}\text { - Australia } \\
\text { - Iran }\end{array}$ & $\begin{array}{l}\text { - China } \\
\text { - Japan }\end{array}$ & $\begin{array}{l}\text { - Burma } \\
\text { - South Korea }\end{array}$ & $\begin{array}{l}\text {-European Union } \\
\text { United States }\end{array}$ \\
\hline
\end{tabular}

\begin{tabular}{|l|l|l|}
\hline \multicolumn{3}{|c|}{ SAARC ENT Conferences } \\
\hline & year & Venue \\
\hline $1^{\text {st }}$ & 1998 & Dhaka, Bangladesh \\
\hline $2^{\text {nd }}$ & 2000 & Kathmandu, Nepal \\
\hline $3^{\text {rd }}$ & 2002 & Islamabad, Pakistan \\
\hline $4^{\text {th }}$ & 2004 & Colombo, Sri Lanka \\
\hline $5^{\text {th }}$ & 2006 & New Delhi, India \\
\hline $6^{\text {th }}$ & 2008 & Dhaka, Bangladesh \\
\hline $7^{\text {th }}$ & 2011 (proposed) & Kathmandu, Nepal \\
\hline
\end{tabular}

